РЕЦЕНЗИЯ НА:

ПЕРЕВОЩИКОВ Д. В. ИНОСТРАННЫЕ ВОЕННОПЛЕННЫЕ В УДМУРТИИ В 1941-1949 ГГ.: МОНОГРАФИЯ

Исследование общей темы «Удмуртия в годы Великой Отечественной войны» в советский период и вплоть до окончания 1990-х гг. в региональной историографии осуществлялось в русле двух основных направлений: 1) всенародная помощь фронту; патриотический вклад тружеников тыла Удмуртской АССР в Великую Победу; 2) воины республики на фронтах Великой Отечественной войны. Ситуация постепенно начала меняться только в последние десятилетия, когда появились работы, анализирующие ранее не изучавшиеся проблемы истории Удмуртии военных лет, где авторы обратились и к сюжетам, говорить о которых прежде было не принято. Таким исследованием стала монография ст. науч. сотр. Удмуртского института истории, языка и литературы (УИИЯЛ) Удмуртского федерального исследовательского центра (УдмФИЦ) УрО РАН, канд. ист. наук Д. В. Перевощикова - «Иностранные военнопленные в Удмуртии в 1941-1949 гг.» [Перевощиков 2019]. До недавнего времени тема иностранных военнопленных на территории Удмуртской АССР (немцев, румын, венгров и др.) оставалась «белым пятном», прежде всего, в таком важном для истории региона контексте, как использование труда военнопленных в народном хозяйстве республики в период войны и в первые послевоенные годы.

Актуальность темы монографии не вызывает сомнений и обусловлена, прежде всего, активизацией в западной политической практике тенденции к фальсификации истории Второй мировой войны, что выражается также и в возникших не сегодня попытках уравнять нацизм и сталинизм (коммунизм / социализм) и возложить на Советский Союз равную с Германией ответственность за развязывание глобального вооружённого конфликта. В стремлении к такому уравниванию не последнюю роль играют активно предпринимаемые попытки уподобления советских пунктов содержания военнопленных нацистским концентрационным лагерям, что находит отражение и в историографии, причём не только на Западе, но и в России. Тема монографии актуальна и в контексте общего оживления научных исследований в этом направлении в субъектах Российской Федерации, в т. ч. в финно-угорских: в 2013 г. было опубликовано монографическое исследование Л. И. Вавулинской, посвящённое проблеме спецпереселенцев и иностранных военнопленных в Карелии в середине 1940-х - середине 1950-х гг. [Вавулинская 2013].

Монография состоит из введения, трёх глав, заключения, списка источников и литературы. В главе 1 «Иностранные военнопленные в лагерях НКВД (МВД) СССР», включающей три параграфа, рассматриваются размещение, условия содержания, снабжение спецконтингента (§ 1.1); численность и национальный состав военнопленных (§ 1.2); антифашистские и культурно-воспитательные мероприятия в лагерях (§ 1.3). Глава 2 «Медицинское обслуживание военнопленных», состоящая из двух параграфов, посвящена вопросам функционирования спецгоспиталей на территории Удмурт- 
ской АССР (§ 2.1) и организации медико-санитарного обеспечения в лагерях (§ 2.2). В двух параграфах главы 3 «Использование труда спецконтингента» речь идет о трудовой деятельности военнопленных в промышленности и строительстве (§ 3.1) и об их заработной плате (§ 3.2).

Монография подготовлена на основе значительного корпуса неопубликованных материалов, хранящихся в центральных (ГА РФ, РГВА), региональных (ЦГА УР, ЦДНИ УР), местных (городов и районов УР) архивах, и опубликованных источников (нормативных актов, периодической печати, источников личного происхождения), введённых автором в научный оборот, а также с опорой на достижения предшествующей историографии.

Научное и историографическое значение работы определяется тем, что автор впервые в региональной историографии предпринял попытку всестороннего анализа вопросов деятельности иностранных военнопленных на территории Удмуртской АССР в 1941-1949 гг., в т. ч. трудового использования спецконтингента, его реальной роли в развитии народного хозяйства республики в военный период и в первые послевоенные годы. В определённой степени исследование Д. В. Перевощикова заполняет известную историографическую лакуну.

Пожалуй, впервые, хотя и ориентировочно, Д. В. Перевощиков попытался определить и численность иностранных военнопленных на территории Удмуртской АССР, а также охарактеризовать их национальный состав, поскольку, помимо немцев, здесь были и румыны, и венгры, и австрийцы, и др. - всего представители около двадцати пяти национальностей. Однако, по всей видимости, из-за недостатка источников, чётко разграничить национальный состав автору не удалось, что не помешало ему сделать вывод о почти пропорциональном соответствии национального состава контингента военнопленных, находившихся на территории Удмуртской АССР в 1941-1949 гг., и степени участия стран Европы в войне против Советского Союза [Перевощиков 2019, 80].

Вместе с тем, исследователь внёс свой вклад и в противодействие попыткам фальсификации истории Второй мировой войны, на региональном материале наглядно и убедительно доказав неправомерность и несостоятельность сравнения пунктов содержания военнопленных в СССР с нацистскими концентрационными лагерями.

Таким образом, рецензируемая работа, безусловно, является новаторской, поскольку, как отмечено выше, представляет собой первое в региональной историографии Удмуртии монографическое исследование заявленной темы.

В то же время исследование Д. В. Перевощикова не свободно от недоработок и недостатков, соображения по поводу которых хотелось бы высказать.

1. Введение излишне подробно: очевидно, оно полностью повторяет вводную часть диссертационной работы автора, что в итоге «утяжелило» текст. Представляется, что в этом не было необходимости, тем более, что жанр монографии свободен от обязательных требований, предъявляемых к диссертационным исследованиям.

Так, наряду с другими частями введения (напр., принципы исторического познания, методы научного исторического исследования и др.), можно было бы опустить и подробный историографический обзор. Однако, поскольку таковой во введении всё же присутствует, следует заметить, что автор, детально останавливаясь на степени изученности проблемы в отдельных регионах России, в то же время посвящает всего семь строк текста [Перевощиков 2019, 18] работам В. П. Мотревича. Между тем, это единственный из российских историков, опубликовавший отдельную статью об иностранных военнопленных на территории Удмуртской АССР [Мотревич 2018/2]. Уральский исследователь, хорошо знакомый с данной темой, является активным участником движения по восстановлению и благоустройству кладбищ, где захоронены иностранные военнопленные. В. П. Мотревич посещал и Удмуртию; он изучил значительный объём архивных материалов по данной теме, в т. ч. и в центральных архивах. Полагаем, что следовало бы показать вклад В. П. Мотревича в изучение проблемы более подробно, тем более что ряд его выводов не совпадает с позицией Д. В. Перевощикова. В частности, рассматривая вопрос о времени пребывания иностранных военнопленных на территории Удмуртской АССР, В. П. Мотревич отмечает, что они появились здесь только в 1942 г. Расходятся исследователи и в вопросе о количестве погибших иностранных военнопленных: если у Д. В. Перевощикова указано 3766 чел. [Перевощиков 2019, 123], то у В. П. Мотревича - 3679 чел. [Мо- 
тревич 2018/2, 197]. В другой своей статье В. П. Мотревич указывает на 4967 иностранных военнопленных, погибших на территории Удмуртской АССР в 1944-1949 гг. [Мотревич 2018/1, 198]. Однако Д. В. Перевощиков эту статью в своей работе, по всей видимости, не учитывал. На наш взгляд, имело смысл также привлечь и приведённые В. П. Мотревичем данные о национальном составе погибших иностранных военнопленных, среди которых было 2589 немцев, 398 румын, 189 венгров и 163 итальянца. Правда, исследователь обращает внимание на расхождения в определении их численности: так, в некоторых источниках говорится о 210 пленных венграх [Мотревич 2018/1, 199; Мотревич 2018/2, 197].

Кроме того, непонятно, учитывал ли автор в качестве источников законодательные акты, в т. ч. международные договоры. Во всяком случае, о таковых во введении монографии не упоминается. При этом автор ссылается как на одну из составляющих источниковой базы своей работы на опубликованные сборники документов (напр.: Внешняя политика Советского Союза в период Отечественной войны. Документы и материалы. Т. І. М., 1946; Т. III. М., 1947; и др.) [Перевощиков 2019,21]; а также - как на один из компонентов методологической основы исследования - на институциональный подход, который «позволил рассмотреть военный плен как международно-правовой институт, определяющий основные правила обращения с обезоруженными представителями противоборствующей стороны» [Перевощиков 2019, 27].

Следует обратить внимание и на противоречие между отмеченной автором во введении «заметной ролью в послевоенном восстановлении промышленности и хозяйства Советского Союза, которую сыграли бывшие военнослужащие из разгромленных армий фашистского блока» [Перевощиков 2019, 3], и одним из выводов третьей главы об экстенсивности и малой эффективности их трудовой деятельности [Перевощиков 2019, 154]. К тому же автор многократно приводит факты, свидетельствующие о том, что на работы выходила меньшая часть военнопленных.

2. На наш взгляд, автору имело смысл более основательно поработать над систематизацией материала. В существующем виде следует признать её не вполне удачной. В частности, структуру монографии можно было бы выстроить несколько иначе. Так, параграф 1.3, посвящённый антифашистским и культурно-воспитательным мероприятиям в пунктах содержания военнопленных, учитывая особую важность этого направления работы со спецконтингентом, имело смысл выделить в отдельную главу. В главу 2 из главы 1 следовало перенести материал об условиях содержания и снабжении военнопленных и обозначить это отдельным параграфом. В таком случае структура исследования стала бы, на наш взгляд, более логичной: 1) размещение, количественный и национальный состав; 2) условия содержания и снабжение военнопленных (включая и медицинское обслуживание); 3) использование труда спецконтингента в народном хозяйстве Удмуртской АССР; 4) политико-идеологическая работа с военнопленными и организация их культурно-воспитательного досуга.

Кроме того, некоторые сюжеты в тексте монографии не вполне вписываются в те её разделы, в которых фактически присутствуют, и с точки зрения смысла было бы логичнее поместить их в другие разделы работы. Так, сюжет про саботаж и существование подпольных групп выглядел бы более уместно в разделе об антифашистской агитационной работе, а материал о захоронениях иностранных военнопленных на территории Удмуртии можно было поместить в параграф об их количественном и национальном составе.

Следует также заметить, что автор излагает материал, характеризуя жизнедеятельность военнопленных поочерёдно в каждом из пунктов их содержания на территории Удмуртской АССР («в одном лагере...; в другом лагере...»). Логичнее было бы сгруппировать материал по смысловым блокам, выявляя и характеризуя общее, а на примере конкретных пунктов содержания военнопленных показывать особенное, акцентируя, таким образом, внимание на специфике каждого из них.

3. Формулируя цель исследования, автор пишет, что таковой «является реконструкция политико-правового и социально-экономического аспектов жизнедеятельности военнопленных в Удмуртии в 1941-1949 гг. в контексте общесоюзной ситуации» [Перевощиков 2019, 20] (курсив наш, - Aвm.), но трактует этот контекст лишь как «всецело учитывающий общую политическую и особенно экономическую обстановку в СССР и Удмуртии в 1941-1949 гг.» [Перевощиков 2019, 174]. Между тем, полагаем, что названный контекст подразумевает и сравне- 
ние различных сторон жизнедеятельности иностранных военнопленных в Удмуртской АССР с таковыми в других регионах Советского Союза. Подобный сравнительный анализ позволил бы выявить региональную специфику Удмуртии и сделать исследование более полным, тем более что материал для этого, судя по проведённому во введении подробному историографическому обзору, в распоряжении автора имелся. В итоге, констатация, что в монографии «рассмотрены особенности пребывания иностранных военнопленных на территории Удмуртии в период 1941-1949 гг.» [Перевощиков 2019, 30], представляется не вполне обоснованной.

4. Антифашистская агитационно-идеологическая работа среди спецконтингента охарактеризована автором, главным образом, путём перечисления её организационных форм вперемешку с описанием быта военнопленных. Обобщению и осмыслению идейного содержания этой работы во всех пунктах пребывания военнопленных на территории Удмуртской АССР уделено существенно меньше внимания. Вместе с тем, учитывая особую важность этого направления работы со спецконтингентом с точки зрения международной политики, послевоенного устройства Германии и Европы в интересах мира, этот сюжет следовало осветить более основательно. В частности, системно подойти к анализу содержания тематических занятий с военнопленными, а главное - в системном же контексте сформулировать общие цели и задачи антифашистской агитационно-идеологической работы. Последняя, как указывает автор в отношении одного из спецгоспиталей, была ориентирована на то, чтобы «организационно и идеологически подготовить оставшихся военнопленных к репатриации и постараться убедить их в необходимости борьбы за единую демократическую Германию», а также «на укрепление товарищеских отношений между советским и немецким народами» [Перевощиков 2019, 92-93]. В соответствующем разделе монографии осмысление этого сюжета в контексте темы недостаточно выражено.

В заключение следует отметить, что высказанные замечания не умаляют достоинств рецензируемой работы, поскольку это первый и новаторский опыт исследования заявленной темы. Конечно, не все вопросы удалось всесторонне осветить. В частности, не установлены окончательно численность иностранных военнопленных в Удмуртской АССР и их национальный состав, не рассмотрена в полной мере проблема репатриации и др.

Вместе с тем, не вызывает сомнений, что монография Д. В. Перевощикова является не только весомым вкладом в региональную историографию Великой Отечественной войны в целом, но и дает толчок новым плодотворным исследованиям и дискуссиям по данной проблеме. Работа представляет безусловный интерес для узких специалистов, а также может быть полезной для преподавателей вузов, учителей, студентов и всех интересующихся проблемами истории Великой Отечественной войны.

\section{ЛИТЕРАТУРА}

Вавулинская Л. И. Спецпереселенцы и иностранные военнопленные в Карелии в середине 1940-х середине 1950-х гг. Петрозаводск: Карельский научный центр РАН, 2013337 с.

Мотревич В. П. Венгерские воинские захоронения второй мировой войны на Урале: численность, дислокация, благоустройство // Проблемы истории Венгрии и российско-венгерских отношений: сб. науч. ст. / отв. ред. А. С. Смыкалин. Екатеринбург: УрГЮУ, 2018. С. 194-214.

Мотревич В. П. Учреждения для военнопленных и интернированных в Удмуртской АССР в 1942-1949 гг.: численность, дислокация, смертность контингента // Вестн. Оренб. гос. пед. ун-та: электрон. науч. журн. 2018. № 4. С. 192-204.

Перевощиков Д. В. Иностранные военнопленные в Удмуртии в 1941-1949 гг.: монография / отв. ред. Л. Н. Бехтерева; УИИЯЛ УдмФИЦ УрО РАН. Ижевск: Изд-во «АлкиД», 2019. 188 с.

Прислано в редакцию 11.01.2021

Репников Дмитрий Викторович, кандидат исторических наук, доцент ФГБОУ ВО «Удмуртский государственный университет» 426034, Россия, г. Ижевск, ул. Университетская, 1 (корп. 6) e-mail: repnikov@udm.ru 
Уваров Сергей Николаевич, кандидат исторических наук, ФГБОУ ВО «Ижевская государственная сельскохозяйственная академия» 426069, Россия, г. Ижевск, ул. Студенческая, 11 e-mail: sergey.uvarov@mail.ru

\title{
D. V. Repnikov, S. N. Uvarov \\ REVIEW OF: PEREVOSHCHIKOV D. V. FOREIGN PRISONERS OF WAR IN UDMURTIA IN 1941-1949: MONOGRAPH
}

\author{
DOI: $10.35634 / 2224-9443-2021-15-1-183-187$
}

Citation: Yearbook of Finno-Ugric Studies, 2021, vol. 15, issue 1, pp. 183-187. In Russian.

\section{REFERENCES:}

Vavulinskaya L. I. Spetspereselentsy i inostrannyye voyennoplennyye v Karelii v seredine 1940-kh - seredine 1950-kh gg. [Special settlers and foreign prisoners of war in Karelia in the mid-1940s - mid-1950s]. Petrozavodsk, Ed. of the Karelian Scientific Center of the Russian Academy of Sciences, 2013, 337 p. In Russian.

Motrevich V. P. Vengerskiye voinskiye zakhoroneniya vtoroy mirovoy voyny na Urale: chislennost', dislokatsiya, blagoustroystvo [Hungarian military graves of World War II in the Urals: number, deployment, improvement]. Problemy istorii Vengrii i rossiysko-vengerskikh otnosheniy: sbornik nauchnykh statey / otvetstvennyy redaktor A. S. Smykalin [Problems of the history of Hungary and Russian-Hungarian relations: collection of scientific articles / executive editor A. S. Smykalin]. Yekaterinburg, Ural State University of Law Press, 2018. Pp. 194-214. In Russian.

Motrevich V. P. Uchrezhdeniya dlya voyennoplennykh i internirovannykh v Udmurtskoy ASSR v 1942-1949 gg.: chislennost', dislokatsiya, smertnost' kontingenta [Institutions for prisoners of war and internees in the Udmurt Autonomous Soviet Socialist Republic in 1942-1949: size, deployment, mortality of the contingent]. Vestnik Orenburgskogo gosudarstvennogo pedagogicheskogo universiteta: elektronnyy nauchnyy zhurnal [Bulletin of the Orenburg State Pedagogical University: electronic scientific journal], 2018. No. 4. Pp. 192-204. In Russian.

Perevoshchikov D. V. Inostrannyye voyennoplennyye v Udmurtii v 1941-1949 gg.: monografiya / otvetstvennyy redaktor L. N. Bekhtereva; Udmurtskiy institut istorii, yazyka i literatury Udmurtskogo federal'nogo issledovatel'skogo tsentra Ural'skogo otdeleniya Rossiyskoy akademii nauk [Foreign prisoners of war in Udmurtia in 1941-1949: monograph / executive editor L. N. Bekhtereva; Udmurt Institute of History, Language and Literature of the Udmurt Federal Research Center of the Ural Branch of the Russian Academy of Sciences]. Izhevsk, “AlkiD” Publ., 2019. 188 p. In Russian.

Reseived 11.01.2021

Repnikov Dmitry Viktorovich, Candidate of History, Associate Professor Udmurt State University

Universitetskaya st., 1/6, Izhevsk, 426034, Russia e-mail: repnikov@udm.ru

Uvarov Sergey Nikolaevich, Candidate of History, Izhevsk State Agricultural Academy Studencheskaya st., 11, Izhevsk, 426069, Russia e-mail: sergey.uvarov@mail.ru 